\title{
Implementation of Pneumatic Module Based on Interactive Computer Learning
}

\author{
Agung Prijo Budijono, Wahyu Dwi Kurniawan \\ Mechanical Engineering Department \\ Universitas Negeri Surabaya \\ Surabaya, Indonesia \\ agungbudijono@unesa.ac.id
}

\begin{abstract}
Using Module Based on Interactive Computer with FluidSIM-P3 Pneumatic System Simulation Software becomes the media for students to explore more experiences related to Hydraulic System. The objective of this study is to improve quality of learning based on activities, motivation, responses and learning result of students. Data retrieval used were questionnaire responses, observation sheets and final test. The observation result showed that the activities of lecturer and students enhanced during learning process of Pneumatic and Hydraulic by using Module Based on Interactive Computer. The improvement was from the first cycle to the second one with the average value $66.63 \%$ for the first one and $86.88 \%$ belong to the second one. The enhancement learning of students showed $73 \%$ of the first one and $100 \%$ of the second one, meanwhile the response results of this module showed $91.8 \%$.
\end{abstract}

Keywords-module, interactive, computer, pneumatic, hydraulic

\section{INTRODUCTION}

Industrial development is growing fast, thus, it depends on educational institutions especially universities to transfer technological knowledge. It is expected that the graduates are competent at their field and suitable for industries. Mechanical Engineering Department at Surabaya State University has one of subject related to industrial standard competence that is pneumatic and hydraulic. The students have to comprehend it to be able to compete at industries. Unfortunately, they have difficulty in comprehending pneumatic system, they made a circuit but do not know more about it. The learning tool does not exist so that they do not know how pneumatic system works.

The observation showed that the subject of pneumatic and hydraulic was taught by lecture method, i.e. taught through words only. The media used were only LCD and some text books. This condition made the students passive and the interaction in the class was not conducive. The impact was terrible, i.e. the learning result and achievement of all students in the class were poor.

Referring to that case, the learning method needs to be changed into using module based on interactive computer with FluidSIM-P3 pneumatic system simulation software. This option will motivate students more to explore about pneumatic and hydraulic. It will also improve the learning result of them

FluidSIM-P3 Software is a program that can simulate how the pneumatic system works. It is equipped with pneumatic components in the form of symbols. The following is the view of it.

The aims of this research are 1) explain lecturer's activities during pneumatic and hydraulic learning by using interactive computer-based module, 2) explain students' activities during pneumatic and hydraulic learning by using interactive computer-based module, 3) explain students' learning outcomes during pneumatic and hydraulic learning by using an interactive computer-based module, and 4) explain students' response during pneumatic and hydraulic learning by using interactive computer-based module.

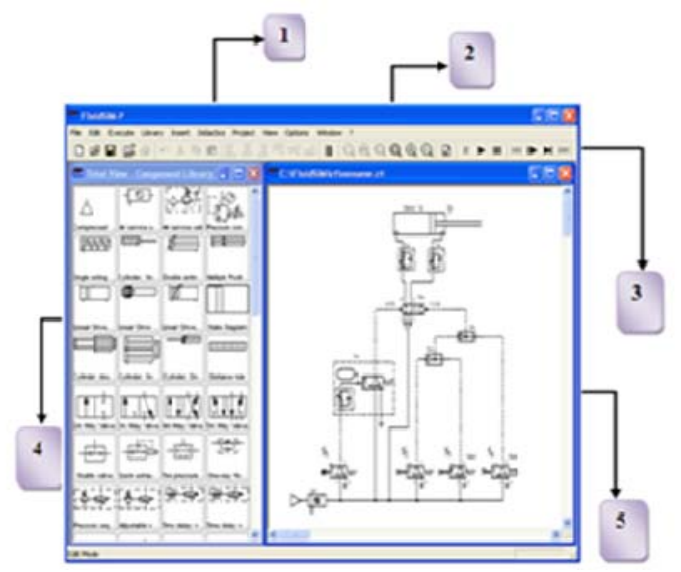

Fig. 1. Interface of FluidSIM-P3

Annotation : (1) Titlebar is the title line that contains the name of the file to be created, (2) Menubar is the line where the programming command menus are located. It consists of: File, Edit, Execute, Library, Insert, Didactics, Project, View, Options, Window and Help (?). Each category has a sub menu box that contains its own programming commands. (3)Toolbar is a group of icons (images) that represent commands and functions to execute commands easily and quickly. These are some explanations of the functions of the Toolbar, (4) Component Library is a group of pneumatic components both electrical and mechanical to create pneumatic circuit diagrams. These groups are symbolized with pneumatic icon in pneumatic circuit diagrams. (5) Editing View is the worksheet in the form of circuit diagrams to write the instructions of the simulation program of FluidSIM-P3. It consists of pneumatic circuit diagrams. 


\section{METHOD}

This study is an action research which has spiral form from one cycle to another one. It contained plan, action, observation and reflection. The next one includes revised plan, action, observation and reflection. Before reaching the first one, it was a preliminary action in the form of problem identification.

This research was carried out at the Department of Mechanical Engineering Faculty of Engineering, State University of Surabaya in the even Semester in the academic year 2008/2009.

Subjects in this study were students of D-3 Production of Mechanical Engineering Department 2007 programmed pneumatic and hydraulic courses. The object of this research is interactive computer-based learning tool. Instruments used to collect data in this study are as follows.

- Questionnaire, used to know the students' response.

- The observation sheet used to observe lecturer and students' activities during pneumatic and hydraulic learning activities using an interactive computerbased module.

- The test used to determine the extent of learning mastery by using an interactive computer-based module.

To know the effectiveness of a method in learning activities data analysis was done. This study used qualitative descriptive analysis techniques to determine students' achievement, obtain students' responses to learning activities and describe students' activities during the learning process.

\section{RESULT AND Discussion}

\section{A. The First Cycle}

1) The Planning Stage of the First One

At this stage the researcher prepared learning tools, observation sheets, evaluation test questions 1 and supportive teaching tools.

\section{2) The Action Stage of the First One}

The interaction of learning process was held in the CNC Room A6 Building 1st Floor followed by as many as 26 students. In this case the researcher acted as an observer. The learning process referred to his plans has been prepared. Observation was carried out simultaneously with lecture activities.

At the end of it, the students were given formative test I with the aim to know their achievement in learning. The research results in the first cycle were as follows :

\section{a) The data of activity observation}

The number of observers was 3 . The number of questions list of observation were 16 (Appendix 1) with detail of 8's of lecturer's activity when teaching, 8's of the activity of students when learning. These data can be shown as follow at Table I and Table II.
TABLE I. THE RESULT OF LECTURER OBSERVATION IN THE FIRST CYCLE

\begin{tabular}{|l|l|l|l|l|l|l|}
\hline \multirow{2}{*}{ No } & \multirow{2}{*}{$\begin{array}{l}\text { Question } \\
\text { Number }\end{array}$} & \multicolumn{3}{|c|}{$\begin{array}{c}\text { The Assessment of } \\
\text { Reviewer }\end{array}$} & \multirow{2}{*}{ Average } & $\begin{array}{c}\text { Percentage } \\
(\%)\end{array}$ \\
\cline { 3 - 5 } & & $\boldsymbol{R} 1$ & $\boldsymbol{R} 2$ & $\boldsymbol{R} 3$ & & \\
\hline 1 & 1 & 4 & 3 & 4 & 3.6 & 72 \\
\hline 2 & 2 & 4 & 4 & 5 & 4.3 & 86 \\
\hline 3 & 3 & 4 & 4 & 4 & 4 & 80 \\
\hline 4 & 4 & 5 & 5 & 5 & 5 & 100 \\
\hline 5 & 5 & 4 & 4 & 4 & 4 & 80 \\
\hline 6 & 6 & 3 & 3 & 3 & 3 & 60 \\
\hline 7 & 7 & 4 & 4 & 3 & 3.6 & 72 \\
\hline 8 & 8 & 3 & 3 & 3 & 3 & 60 \\
\hline \multicolumn{7}{|c|}{ Total }
\end{tabular}

TABLE II. THE RESULT OF STUDENT OBSERVATION IN THE FIRST CYCLE

\begin{tabular}{|l|c|c|c|c|c|c|}
\hline \multirow{2}{*}{ No } & \multirow{2}{*}{$\begin{array}{l}\text { Question } \\
\text { Number }\end{array}$} & \multicolumn{3}{|c|}{$\begin{array}{c}\text { The Assessment of } \\
\text { Reviewer }\end{array}$} & \multirow{2}{*}{ Average } & $\begin{array}{c}\text { Percentage } \\
(\%)\end{array}$ \\
\cline { 3 - 5 } & & $\boldsymbol{R 1}$ & $\boldsymbol{R} 2$ & $\boldsymbol{R 3}$ & & \\
\hline 1 & 1 & 4 & 4 & 4 & 4 & 80 \\
\hline 2 & 2 & 3 & 3 & 4 & 3.3 & 66 \\
\hline 3 & 3 & 3 & 3 & 3 & 3 & 60 \\
\hline 4 & 4 & 4 & 3 & 3 & 3.3 & 66 \\
\hline 5 & 5 & 4 & 3 & 3 & 3.3 & 66 \\
\hline 6 & 6 & 3 & 3 & 2 & 2.6 & 52 \\
\hline 7 & 7 & 3 & 2 & 3 & 2.6 & 52 \\
\hline 8 & 8 & 4 & 4 & 4 & 4 & 80 \\
\hline
\end{tabular}

Note :

R1 : Reviewer 1

R2 : Reviewer 2

R3 : Reviewer 3

\section{b) The data of evaluation}

It contained formative test I (Appendix 3). It can be seen at Appendix 4 and the recapitulation of the results of students' evaluation test in the first one can be seen in Table III below.

TABLE III. THE RESULT OF EVALUATION IN THE FIRST ONE

\begin{tabular}{|l|l|l|}
\hline No & \multicolumn{1}{|c|}{ Description } & \multicolumn{1}{|c|}{ The Result of $\mathbf{1}^{\text {st }}$ Cycle } \\
\hline 1 & The number of students & 26 \\
\hline 2 & The number of mastery learning & 19 \\
\hline 3 & The number of not mastery learning & 7 \\
\hline 4 & Percentage of mastery learning & $73.04 \%$ \\
\hline
\end{tabular}

\section{3) The Reflection of the First One}

a) The Interaction of Learning Process

Table I and Table II showed that the assessment of observation of lecturer's activity in the first one was $76.25 \%$, categorized as active. On the contrary, the assessment for students was $57 \%$, categorized as active enough. The improvement of lecturer's in this one is included active enough namely in giving the training which indicate $60 \%$ and giving self-training which indicate $60 \%$.

\section{b) The Result of Learning Test}

Table III showed that classical completeness for the formative test I was $73 \%$. It shows that the mastery of Pneumatic and Hydraulic with subject matter Pneumatic system was not reached. Therefore it is necessary to improve the learning methods so that the classical completeness of Pneumatic and Hydraulic materials can be achieved. 


\section{c) The Revision of the First One}

Based on the reflection did, the aspects need to be revised to next one were as follows: (1) Lecturer should be more intensive in guiding the students when doing the task, especially when the students do the simulation, because in the first one they were unfamiliar. Therefore, in the next one, it is expected they get used to use the simulation in their duties. (2) Question and answer session were also required to be improved by giving chance to the students to have a discussion with lecturer or among the students.

\section{B. The Second One}

1) The Planning Stage of the Second One

At this stage the researcher prepares learning tools, observation sheets, evaluation test questions 2 and supportive teaching tools.

2) The Action Stage and Implementation of the Second One

The interaction of learning process was held in the CNC Room A6 Building 1st Floor followed by as many as 26 students. In this case the researcher acted as an observer. The learning process referred to his plans has been prepared. Observation was carried out simultaneously with lecture activities.

\section{a) The data of activity observation}

The number of observers was 3 people. The number of questions list of observation were 16 (Appendix 1) with detail of 8's of lecturer's activity when teaching, 8's of the activity of students when learning. These data can be shown as follow at Table IV and Table V.

TABLE IV. THE RESULT OF LECTURER OBSERVATION IN THE SECOND CYCLE

\begin{tabular}{|c|c|c|c|c|c|c|}
\hline \multirow[t]{2}{*}{ No } & \multirow{2}{*}{$\begin{array}{l}\text { Question } \\
\text { Number }\end{array}$} & \multicolumn{3}{|c|}{$\begin{array}{c}\text { The Assessment of } \\
\text { Reviewer }\end{array}$} & \multirow[t]{2}{*}{ Average } & \multirow{2}{*}{$\begin{array}{c}\text { Percentage } \\
(\%)\end{array}$} \\
\hline & & $R 1$ & $R 2$ & $R 3$ & & \\
\hline 1 & 1 & 5 & 5 & 5 & 5 & 100 \\
\hline 2 & 2 & 5 & 4 & 5 & 4.6 & 92 \\
\hline 3 & 3 & 4 & 4 & 5 & 4.3 & 86 \\
\hline 4 & 4 & 5 & 5 & 5 & 5 & 100 \\
\hline 5 & 5 & 5 & 5 & 4 & 4.6 & 92 \\
\hline 6 & 6 & 4 & 5 & 5 & 4.6 & 92 \\
\hline 7 & 7 & 4 & 4 & 4 & 4 & 80 \\
\hline 8 & 8 & 5 & 4 & 4 & 4.3 & 86 \\
\hline \multicolumn{5}{|c|}{ Total } & 41 & $91 \%$ \\
\hline
\end{tabular}

TABLE V. THE RESULT OF STUDENT OBSERVATION IN THE SECOND CYCLE

\begin{tabular}{|c|c|c|c|c|c|c|}
\hline \multirow{2}{*}{ No } & \multirow{2}{*}{$\begin{array}{c}\text { Question } \\
\text { Number }\end{array}$} & \multicolumn{3}{|c|}{$\begin{array}{c}\text { The Assessment of } \\
\text { Reviewer }\end{array}$} & \multirow{2}{*}{ Average } & $\begin{array}{c}\text { Percentage } \\
\text { (\%) }\end{array}$ \\
\cline { 3 - 5 } & & $\boldsymbol{R} \mathbf{1}$ & $\boldsymbol{R} 2$ & $\boldsymbol{R} 3$ & & 100 \\
\hline 1 & 1 & 5 & 5 & 5 & 5 & 92 \\
\hline 2 & 2 & 5 & 4 & 5 & 4.6 & 80 \\
\hline 3 & 3 & 4 & 4 & 4 & 4 & 72 \\
\hline 4 & 4 & 4 & 3 & 4 & 3.6 & 72 \\
\hline 5 & 5 & 4 & 4 & 3 & 3.6 & 86 \\
\hline 6 & 6 & 4 & 5 & 4 & 4.3 & 80 \\
\hline 7 & 7 & 4 & 4 & 4 & 4 & 80 \\
\hline 8 & 8 & 4 & 4 & 4 & 4 & $\mathbf{8 2 . 7 5 \%}$ \\
\hline
\end{tabular}

TABLE VI. THE RESULT OF EVALUATION IN THE SECOND ONE

\begin{tabular}{|l|l|l|}
\hline No & \multicolumn{1}{|c|}{ Description } & \multicolumn{1}{|c|}{ The Result of $\mathbf{1}^{\text {st }}$ Cycle } \\
\hline 1 & The number of students & 26 \\
\hline 2 & The number of mastery learning & 26 \\
\hline 3 & The number of not mastery learning & 0 \\
\hline 4 & Percentage of mastery learning & $100 \%$ \\
\hline
\end{tabular}

\section{b) The data of evaluation}

It contained formative test II (Appendix 3). It can be seen at Appendix 4 and the recapitulation of the results of students' evaluation test in the second one can be seen in Table VI above

\section{3) The Reflection of the Second One}

\section{a) The Interaction of Learning Process}

Table IV and Table V showed that the assessment of observation of lecturer's activity in the first one was $91 \%$, categorized as very active. On the contrary, the assessment for students was $82.75 \%$, categorized as very active. The improvement did not exist.

\section{b) The Result of Learning Test}

Table IV and Table V showed that the assessment of observation of lecturer's activity in the first one was $91 \%$, categorized as very active. On the contrary, the assessment for students was $82.75 \%$, categorized as very active. The improvement did not exist.

\section{Discussion}

1) The Interaction of lecturer and students during the learning process

The activities of the lecturer and students during the Pneumatic and Hydraulic Lecture with subject matter Pneumatic system can be seen in Table VII below.

TABLE VII. THE RECAPITULATION OF ACTIVITY OF LECTURER AND STUDENTS

\begin{tabular}{|l|l|l|l|l|l|}
\hline No & Description & Lecturer & Students & Average & Category \\
\hline 1 & $1^{\text {st }}$ Cycle & $76.25 \%$ & $57 \%$ & $66.63 \%$ & Active \\
\hline 2 & $2^{\text {nd }}$ Cycle & $91 \%$ & $82.75 \%$ & $86.88 \%$ & $\begin{array}{l}\text { Very } \\
\text { Active }\end{array}$ \\
\hline
\end{tabular}

From Table VI above, it can be seen that the activity of the lecturer and students during the teaching and learning process has improved from the first one to the second one with the percentage of each cycle $66.63 \%$ in the first cycle and $86.88 \%$ in the second one. The lowest value was obtained in the first one, and the highest value was obtained in the second one. It was because in the first one the students were still exploring the materials and lecture model used by lecturers in Pneumatic and Hydraulic lectures. Their activity in the first one, especially in asking question was passive because that was the beginning of studying the material, and they also felt embarrassed to ask. While in the second one they got better understanding and accustomed to the teaching pattern of the lecturer, so that student activity in lecture increase especially activity of asking questions. For the activity of lecturer from the first one to the second one also experienced improvement, especially lecturer activity in preparing learning device and motivating student activity.

\section{2) The Result of Student's Learning}

The result of students' learning from Pneumatic and Hydraulic lecture was obtained from two tests, namely 
formative test I and formative test II. The results of formative tests I and formative tests II, can be seen in the Table VIII below.

TABLE VIII. THE RECAPITULATION OF FORMATIVE TEST I

\begin{tabular}{|l|l|l|l|}
\hline No & \multicolumn{1}{|c|}{ Description } & \multicolumn{1}{c|}{$\begin{array}{c}\text { Total of Mastery } \\
\text { Learning }\end{array}$} & $\begin{array}{c}\text { \% Classical } \\
\text { mastery }\end{array}$ \\
\hline 1 & $1^{\text {st }}$ Cycle & 19 & 73.00 \\
\hline 2 & $2^{\text {nd }}$ Cycle & 26 & 100 \\
\hline
\end{tabular}

From Table VII, it can be seen that the students' learning achievement increase in Pneumatic and Hydraulic with subject matter pneumatic system from the first cycle to the second one, with the percentage of completeness of the first cycle is $73 \%$ and the second one is $100 \%$. Therefore, the class of pneumatic and hydraulic courses was declared "accomplished". The results of this learning test also showed that the learning tools used were very effective, seen from the level of achievement of learning goals that reached 100\% after the students followed the lecture using Module Based on Interactive Computer.

\section{3) The Student's Response}

From the result of questionnaire data disseminated on the students (Table V), it can be seen that the average percentage of student responses to learning using Module Based on Interactive Computer pneumatic system subject was $91.8 \%$. Thus, pneumatic and hydraulic lectures need it to produce effective learning and produce high quality and highly competitive output.

\section{CONCLUSION}

Based on the results of data analysis and discussion, the researcher concludes that: (1) The application of Module Based on Interactive Computer on Pneumatic and Hydraulic cultivation is effective in terms of the increase of student activity assessment, that is the first one $(57 \%)$ and the second $(82.75 \%)$, including highly active category; (2) The implementation of Module Based on Interactive Computer on Pneumatic and Hydraulic is effective in terms of improvement of Lecturer's activity assessment, that is the first one $(76.25 \%)$ including activation category and the second one (91\%), including highly active category; (3) The application of Module Based on Interactive Computer on Pneumatic and Hydraulic has a positive impact in improving students' learning achievement which is marked by the improvement of students' learning mastery in every cycle, that is the first cycle $(73.0 \%)$ and the second one (100\%); (4) Result of students' response to application of pneumatic and hydraulic Module Based on Interactive Computer is equal to $91,8 \%$.

\section{REFERENCES}

[1] Asabere. et al, "Use of Information \& Communication Technology (ICT) in Tertiary Education in Ghana: A Case Study of Electronic Learning (E-Learning)". International Journal of Information and Communication Technology Research. Vol.2, No.1, January 2012, pp. 62-68.

[2] Kwache. P.Z, "The Imperatives of Information and Communication Technology for Teachers in Nigeria Higher Education". MERLOT Journal of Online Learning and Teaching. Vol.3, No.4, December 2007.
[3] Kwartolo. Y, "Teknologi Informasi dan Komunikasi dalam Proses Pembelajaran". Jurnal Pendidikan Penabur. No.14, Tahun ke-9, Juni 2010 .

[4] Merkel, et.al, An Evaluation of Computer Based Instruction in Microbiology. Microbiology Education. New Jersey, 2000.

[5] Pikhomiriv, A Method of Computerized Assesment in Introductory Physics. Europe Journal Physics. United Kingdom, 2000.

[6] Rumpagaporn, et al, "Students' Critical Thinking Skills in a Thai ICT Schools Pilot Project". International Education Journal. Vol. 8 No 2 November 2007, pp. 125-132.

[7] Smaldino, S.E, dkk. Instructioal Technology and Media for Learning (Ninth Edition). New Jersey Pearson Merril Prentice Hall, 2008.

[8] Suharsimi. Arikunto, Suhardjono, and Supardi, Classroom Action Research. Jakarta: Sinar Grafika offset, 2006.

[9] Suryosubroto, Teaching System With Modules. Yogyakarta: PT. Bina Aksara, 1983.

[10] Vembriarto, Introduction to Teaching Module. Yogyakarta: Yayasan Pendidikan Paramita, 1985. 